\title{
Changes in precipitation over southern Africa during recent centuries
}

\author{
David J. Nash a,b
}

\section{Affiliations:}

a School of Environment and Technology, University of Brighton, Lewes Road, Brighton BN2 4GJ, United Kingdom.

b School of Geography, Archaeology and Environmental Studies, University of the Witwatersrand, Private Bag 3, Wits 2050, South Africa.

E-mail address: d.j.nash@brighton.ac.uk

\section{Summary:}

Precipitation levels in southern Africa exhibit a marked east-west gradient, and are characterised by strong seasonality and high interannual variability. Much of the mainland south of $15^{\circ} \mathrm{S}$ exhibits a semi-arid to dry subhumid climate. More than $66 \%$ of rainfall in the extreme southwest of the subcontinent occurs between April and September. Rainfall in this region - termed the "winter rainfall zone" (WRZ) - is most commonly associated with the passage of mid-latitude frontal systems embedded in the austral westerlies. In contrast, more than $66 \%$ of mean annual precipitation over much of the remainder of the subcontinent falls between October and March. Climates in this "summer rainfall zone" (SRZ) are dictated by the seasonal interplay between subtropical high-pressure systems and the migration of easterly flows associated with the Intertropical Convergence Zone. Fluctuations in both SRZ and WRZ rainfall are linked to variability of sea surface temperatures in the oceans surrounding southern Africa, and are modulated by the interplay of large scale modes of climate variability, including the El Niño-Southern Oscillation (ENSO), Southern Indian Ocean Dipole and Southern Annular Mode.

Ideas about the nature of long-term rainfall variability in southern Africa have shifted over time. During the early- to mid-19th century, the prevailing narrative was that the climate was progressively desiccating. By the late-19th to early-20th century, when gauged precipitation data became more readily available, debate shifted towards the identification of cyclical rainfall variation. The integration of gauge data, evidence from historical documents, and information from natural proxies such as tree-rings during the late-20th and early 21 st centuries has allowed the nature of precipitation variability since $\sim 1800$ to be more fully explored.

Drought episodes affecting large areas of the SRZ occurred during the first decade of the 19th century, in the early and late 1820 s, late 1850 s-mid 1860 s, mid-late 1870 s, early-mid 1880 s and mid-late 1890 s. Of these, the drought during the early 1860 s was the most severe of the 19th century, with the droughts of the 1820 s and 1890 s the most protracted. Many of these droughts correspond with more extreme ENSO warm phases. Widespread wetter conditions are less easy to identify. The year 1816 appears to have been relatively wet across the Kalahari and other areas of south central Africa. Other wetter episodes were centred on the late 1830 s-early 1840s, 1855, 1870 and 1890. In the WRZ, drier conditions occurred during the first decade of the 19th century, for much of the mid-late 1830s through to the mid-1840s, during the late 1850 s and early 1860 s, and in the early-mid 1880 s and mid-late 
1890s. As for the SRZ, markedly wetter years are less easily identified, although the periods around 1815 , the early 1830 s, the mid 1840 s, mid-late 1870 s and early 1890s saw enhanced rainfall. Reconstructed rainfall anomalies for the SRZ suggest that, on average, the region was significantly wetter during the 19th century than the 20th, and that there appears to have been a drying trend during the 20th century that has continued into the early 21 st. In the WRZ, average annual rainfall levels appear to have been relatively consistent between the 19th and 20th centuries, although rainfall variability increased during the 20th century compared to the 19th.

Keywords: Southern Africa, rainfall variability, 19th century, precipitation reconstruction, documentary sources 


\section{Introduction}

Interannual and interdecadal variations in precipitation have had major implications for human livelihoods and societies across southern Africa throughout the historical period (see Hall, 1976; Smith et al., 2007; Hannaford and Nash, 2016 for examples). Rainfall variability, and in particular drought, is one of the most frequently cited drivers of food insecurity in the subcontinent, primarily because it acts both as an underlying, ongoing issue affecting food production, but also as a short-lived shock (Gregory et al., 2005). In most years, prices for staple food products such as maize grain stabilise or decrease towards the end of the austral summer, because of increased availability following harvests at the local and/or household level. However, during extreme drought years, such as the one that followed the very strong El Niño event of 2015-16, local harvests may fail, triggering food shortages, high prices, and the need for alternative food supplies or aid (UN Office for the Coordination of Humanitarian Affairs, 2015). Failure of the rains during the sowing season may have even more devastating effects.

Some authors (e.g. Gregory et al., 2005; Funk et al., 2008) argue that climate change, through its impacts on regional temperatures and/or rainfall distribution, will induce adverse stresses on southern African food production systems in the future. However, such concerns are not unique to the 21st century. The notion that the subcontinent has undergone long-term environmental changes, including shifts in precipitation levels, and that these changes impact upon agricultural systems, has roots extending at least as far back as the late 18th century. The prevailing view presented by early travellers and explorers was that the subcontinent had been significantly wetter in the past, and was progressively drying up. For example, the French explorer François Le Vaillant described abundant fauna during his travels near Cradock in the Eastern Cape, South Africa, in an area too dry during the early 21st century to support such populations (Le Vaillant, 1796). The English statesman, Sir John Barrow, further attributed the vegetation cover found in parts of the Karoo to wetter conditions in the past (Barrow, 1801, 1804). A desiccation narrative is also prevalent within oral histories recorded in a number of 19th century monographs. In his book Travels in South Africa, for example, the missionary John Campbell includes reference to interviews with people living near the ephemeral Kuruman River in the Northern Cape, all of whom suggested that it was a "great river" in the 
past (Campbell, 1822, Vol. 2, p.93). When questioned, Cornelius Kok, the son of the early settler Adam Kok, further noted that "... in his younger days the Krooman, in the Great [Kalahari] Desert, was a wide and strong river, reaching above his middle... He thought it had been dry or drying up for the last 28 years" (Vol. 2, pp.267-268). Influential 19th century writers such as the missionary Robert Moffat (1842) and missionary-explorer David Livingstone also published their views on regional desiccation, with Livingstone describing evidence for former expanses of standing water in areas of central southern Africa that are semi-arid to arid (Livingstone, 1857). Other authors, including James Fox Wilson (himself influenced by the writings of Moffat and Livingstone), were firmly of the opinion that the Kalahari had become drier. Wilson wrote, for example, of "A very noticeable physical fact..." that "...large tracts of country..." had been drying up in the 1850s and 1860s (Wilson, 1865, p.106). However, as discussed below (section 3.1), the instrumental precipitation data needed to test this hypothesis were not available for several decades.

By the early 20th century, debate had shifted away from the relatively simple idea that southern Africa was progressively desiccating - although desiccation theory still had its proponents (e.g. Barber, 1910; Schwarz, 1920; Kokot, 1948) - towards the identification of cyclical rainfall variation. Ideas concerning the possible cyclical nature of rainfall over South Africa had first been put forward in the late 19th century, with Hutchins (1888), for example, suggesting on the basis of analyses of sunspot and meteorological records, that the Cape had experienced 12 year cycles of relatively high and low rainfall. A study by Nevill (1908) subsequently found evidence for an 18 year periodicity in the rainfall of the former Natal Province, while Cox (1925) identified a 14 year cycle in rainfall data for Cape Town (although this was later refuted). Despite the limited temporal span of the instrumental records used in these early studies, the cycles identified stand up well against more recent investigations of rainfall variability that are based on over a century's worth of data (e.g. Tyson, 1978; Tyson, 1986; and see section 2.2).

Our knowledge of long-term precipitation variability in southern Africa owes much to these early studies, together with the legacy of several highly influential climatic atlases and syntheses of instrumental data published during the mid to late 20th century (e.g. Jackson, 1942; Jackson, 1961; Schulze, 1972, 1984; Tyson, 1986; Schulze, 1997; Tyson and Preston-Whyte, 2000; Schulze, 2001). It also owes 
considerably to the advances made in historical climatological research, specifically in the use of documentary evidence to reconstruct rainfall variability for periods prior to the instrumental record (e.g. Nicholson, 1979, 1981; Vogel, 1989; Nash and Endfield, 2002a; Nicholson et al., 2012a; Nash et al., 2016), and to the development of novel palaeoclimatic proxies for even earlier periods (see Hannaford and Nash, 2016, for examples).

The aim of this article is to provide a critical overview of the evidence for precipitation changes across southern Africa, south of the Zambezi River, during recent centuries. "Recent centuries" are defined here as spanning the period from the late 18 th to the early 21 st century. It begins with a review of our understanding of the contemporary climatology of southern Africa (section 2), before considering the main lines of evidence and methods used to reconstruct historical climate variability across the subcontinent (section 3). The evidence for changes since 1800 (section 4) are then considered, with greatest emphasis given to changes during the period of written and instrumental record. The article concludes (section 5) with a consideration of gaps in our knowledge, and some possible directions for future research.

\section{Contemporary climatology of southern Africa}

\subsection{Spatial variability and seasonality}

Precipitation levels in southern Africa exhibit a marked east-west gradient (Fig. 1), and are characterised by strong seasonality and high interannual variability, with the coefficient of variation exceeding $40 \%$ in drier western areas (Tyson, 1986). Rainfall patterns are influenced by a range of atmospheric and oceanic circulation systems. Rainfall in the extreme southwest of the subcontinent (from approximately $31-34^{\circ} \mathrm{S}$, $17-21^{\circ} \mathrm{E}$, and inland as far as the Great Escarpment) occurs mainly during the austral winter months and transition seasons, with more than $66 \%$ of mean annual precipitation falling between April and September (AMJJAS on Fig. 1). Rainfall in this area - termed the "winter rainfall zone" (WRZ) - is most commonly associated with the passage of mid-latitude frontal systems embedded in the austral westerlies (Tyson, 1986; Nicholson, 2000; Tyson and Preston-Whyte, 2000; Reason and 
Jagadheesha, 2005), which migrate equatorwards each winter from a position to the south of the African continent. The resulting precipitation along the coastal area varies between $50 \mathrm{~mm}$ and $350 \mathrm{~mm}$ per year, but with marked local patterns (MacKellar et al., 2007). Heavier rainfall is generally received when frontal belts are anomalously far north and intensified by ridging to the west. This ridging provides a southerly inflow of cold air into the low pressure cells, increasing cyclonic vorticity (Mason and Jury, 1997).

\section{[Insert Fig. 1 here]}

In contrast, more than $66 \%$ of mean annual precipitation over much of the remainder of the subcontinent (including northern and eastern South Africa, Angola, Botswana, Lesotho, Malawi, Mozambique, Namibia, Swaziland, Zambia and Zimbabwe) falls between the summer months of October and March (ONDJFM on Fig. 1). Climates in this region - termed the "summer rainfall zone" (SRZ) in recognition of the antiphase timing of precipitation compared to the WRZ - are dictated primarily by the seasonal interplay between subtropical high-pressure systems and the migration of easterly flows associated with the Intertropical Convergence Zone (ITCZ) (Chase and Meadows, 2007). The most significant rainfall-producing synoptic systems in the $S R Z$ are tropical-temperate troughs and their associated cloud bands (Tyson, 1986; Mason and Jury, 1997). The development of such troughs over southern Africa is closely linked to sea surface temperature (SST) conditions in the Southwest Indian Ocean (SWIO) (Reason and Mulenga, 1999). An association between warmer SWIO SST anomalies and rainfall in the SRZ has long been recognised. Walker (1990) was the first to suggest that warmer SSTs here were associated with increased easterlies and moisture convergence over tropical and subtropical areas in the east of the subcontinent. Warmer SSTs in the far SWIO, to the south of the African continent, were further linked with enhanced surface fluxes and mid-latitude baroclinicity. Together, these atmospheric modulations promote the formation of tropical-temperate troughs (Reason and Mulenga, 1999). Mason (1995) recognised subsequently that warmer SSTs in the Mozambique Channel and waters south and south-west of Madagascar were the most critical influence upon precipitation levels over much of the SRZ. 
The narrow belt of South Africa between the SRZ and WRZ (Fig. 1) receives both winter and summer precipitation, and is sometimes referred to as the year-round rainfall zone (YRZ) (Chase and Meadows, 2007). Cut-off lows contribute from 25 to more than $35 \%$ of annual precipitation within this transitional zone (Favre et al., 2013), sometimes bringing extreme rainfall and flash flooding (Singleton and Reason, 2007).

\subsection{Influences upon precipitation variability}

As noted in section 1, interannual rainfall variability in southern Africa exhibits statistically significant cyclicity (Tyson, 1978; Tyson, 1986), a phenomenon that has been recognised since the late 19th century (e.g. Hutchins, 1888; Tripp, 1888). A 1012 year oscillation accounts for over $30 \%$ of interannual rainfall variance along the south coast of South Africa (Mason and Jury, 1997). However, of greater significance is an 18-20 year oscillation in rainfall over the northeast of South Africa, that also extends into eastern Botswana, Zimbabwe and southern Mozambique (e.g. Tyson et al., 1975; Tyson, 1986; Lindesay, 1988; Rocha and Simmonds, 1997; Reason and Rouault, 2002). This approximately bi-decadal cycle is more clearly apparent in streamflow than in instrumental rainfall data (see Mason and Jury, 1997).

Fluctuations in both SRZ and WRZ rainfall are linked to variability of SSTs in the oceans surrounding southern Africa (see Tyson, 1986; Mason and Jury, 1997; Goddard and Graham, 1999; Behera and Yamagata, 2001; Reason, 2001; Reason and Jagadheesha, 2005). Higher than average SSTs in the central equatorial Indian Ocean, for example, are frequently responsible for dry conditions over southern Africa (e.g. Walker, 1990; Jury, 1995, 1996; Rocha and Simmonds, 1997), although the response appears to be non-linear (Mason and Jury, 1997). Such fluctuations in SSTs may, in turn, be modulated by the interplay of large scale modes of climate variability, including the EI Niño-Southern Oscillation (ENSO), Southern Indian Ocean Dipole (SIOD) and Southern Annular Mode (SAM). Finally, interannual to decadal scale rainfall variability in northeastern areas of the subcontinent may also be influenced by landfalling tropical cyclones.

The influence of ENSO upon precipitation in southern Africa has been known for more than three decades (cf. Stoeckenius, 1981; Lindesay et al., 1986; Nicholson and Entekhabi, 1986; Ropelewski and Halpert, 1987, 1989; Rocha and Simmonds, 
1997; Reason et al., 2000; Meque and Abiodun, 2015). In general, ENSO only impacts upon southern Africa when the ENSO event has evoked SST changes in both the Atlantic and Indian Oceans (cf. Nicholson et al., 2001). To date, the most comprehensive analysis of ENSO-rainfall relationships in the subcontinent is that of Nicholson and Kim (1997). Their study demonstrates that ENSO warm events (i.e. El Niño) may be preceded by periods of anomalously high rainfall in the $S R Z$, but are more often followed by drought. Over much of the SRZ, the greatest reduction in precipitation is towards the latter part of the rainy season following an EI Niño event. However, in southeastern Africa, the most ENSO-sensitive region of the subcontinent, the maximum response occurs during the peak summer rainfall months of December-March. La Niña events, in contrast, are often associated with wetter summer conditions in the SRZ (Van Heerden et al., 1988; Nicholson and Selato, 2000).

Less is understood about the influence of the SAM and SIOD on southern African rainfall. Positive phases of the SAM are usually associated with anomalously wet conditions over the SRZ and weak decreases in rainfall in the WRZ (Gillett et al., 2006; Watterson, 2009). Rainfall in the north-east of the subcontinent has been shown to be modulated by interactions between ENSO and the SIOD, with positive SOID phases generally associated with enhanced rainfall (Abram et al., 2008).

Tropical cyclone (TC) activity mainly affects northeastern areas of the subcontinent during the austral summer/autumn months of November-April (see Jury, 1993; Reason, 2007; Mavume et al., 2009; Chang-Seng and Jury, 2010; Fitchett and Grab, 2014). Only around 5\% of SWIO TCs make landfall on the southern African mainland. However, a far greater number strike Madagascar, with 48 of the 64 landfalling TCs between 1980 and 2007 impacting upon the island (Mavume et al., 2009). Recent TCs have caused extensive damage to agricultural systems in Madagascar, through both wind impacts and flooding (Brown, 2009), with similar damage described in historical documents from as far back as the middle of the 19th century (Nash et al., 2015). Although less frequent, equivalent impacts have been felt on the mainland. For example, following a tropical depression earlier in the month, Tropical Cyclone Eline in late February 2000 brought about devastating flooding in Mozambique, Zimbabwe, and South Africa (see Reason and Keibel, 2004). Less well-known is that ex-Eline then tracked some $2000 \mathrm{~km}$ across southern 
Africa, bringing significant rainfall to desert regions of Namibia (about $25 \%$ of the January-March 2000 rainfall in southern Namibia resulted from this system; Reason and Keibel, 2004). As with wider rainfall patterns across the subcontinent, SWIO TC activity is also influenced by ENSO. TC genesis is more frequent during EI Niño phases (Ho et al., 2006; Kuleshov et al., 2008), to the extent that ENSO is used as a predictor of TC activity in the SWIO at weekly to monthly timescales (Leroy and Wheeler, 2008; Vitart et al., 2010). The influence of the SIOD on SWIO TCs is less well understood, although it appears to interact with ENSO to influence TC trajectories (Ash and Matyas, 2012). TC passages are also more frequent during Madden-Julian Oscillation phases 2-4 (Ho et al., 2006).

\section{Nature of the evidence for precipitation variability}

\subsection{Instrumental rainfall data}

South Africa has some of the longest-running instrumental precipitation series for the African continent (Nicholson et al., 2012a; Nicholson et al., 2012b). The most readily usable data consist of continuous station records from the mid- to late-19th century (Nicholson, 2001b). The earliest of these are from the Royal Observatory in Cape Town. This was established in 1820 as an astronomical observatory, but, in 1838, also became the first official site in the subcontinent where meteorological data were collected systematically (Hannaford and Nash, 2016). Continuous meteorological records from the Observatory are available within the NOAA Global Historical Climatology Network (GHCN) database from 1850 onwards, with additional data from 1842-1849 preserved within meteorological "day books" held at the Observatory itself (Neukom et al., 2014). Further meteorological recording stations were established in other South African towns and cities, including Aliwal North, Clanwilliam, Graaf Reinet, Grahamstown, Groot Drakenstein, Kingwiliamstown, Pietermaritzburg, Port Elizabeth, Rietfontein, and Uitenhage, in the 1850s and 1860 s, with the gauging network expanded to cover the majority of the country by the end of the 19th century (Fig. 2).

[Insert Fig. 2 here] 
For other parts of the subcontinent, systematic meteorological data collection started much later, with the instrumental period (at least as reflected in the GHCN database) only beginning in the 1850s in Angola, the 1870s in Botswana, the 1880s in Lesotho, Mozambique, Namibia and Zimbabwe, the 1890s in Malawi and Swaziland, and the 1900s in Zambia (Hannaford and Nash, 2016). Many meteorological recording stations in these countries were established by colonial governments, but abandoned with the transition to postcolonial rule during the 20th century. Malawi, for example, had a large number of such stations (Nicholson, 2001b).

Many countries additionally have collections of temporary, non-governmental meteorological observations from the 19 th and early 20th centuries. These were most commonly made at sites such as mission stations and explorer's camps, but, with notable exceptions, rarely span one or two years. For example, the collection of daily weather observations was initiated at Bandawe (from December 1878 to March 1880) and Kaning'ina (December 1878 to September 1879) in Malawi by Scottish missionaries, under the instruction of the Foreign Missions Committee of the Free Church of Scotland ${ }^{1}$, but was discontinued once these mission stations became established.

\subsection{Documentary information}

For periods prior to the start of systematic meteorological data collection, descriptions of weather conditions within historical documents provide one of the most important sources of annually resolved information about past rainfall variability. In southern Africa, a variety of historical sources have been employed for rainfall reconstruction. These include published materials such as newspapers, monographs, travelogues and colonial government reports (e.g. the annual Blue Books produced by the British government for individual former colonies), as well as collections of unpublished letters, diaries and other items of personal correspondence. In this latter category, collections of materials written by representatives of various European Protestant missionary societies have proved

\footnotetext{
${ }^{1}$ National Library of Scotland, Dep.298/139, Livingstonia. Instructions to Lake Nyassa Mission Party from Foreign Missions Committee of the Free Church, with concurrence of Committee of Reformed Presbyterian Church.
} 
particularly informative (see, for example, Endfield and Nash, 2002; Nash and Endfield, 2002a; Kelso and Vogel, 2007; Nash and Grab, 2010).

Three categories of documentary data useful for rainfall reconstruction can be recognised within these historical sources (see Nicholson, 2001b). The first are what might be described as direct references to climate and meteorology. These include actual measurements of rainfall, sometimes as part of specially compiled weather diaries (see Adamson, 2015) or within newspapers (Nash and Adamson, 2014), as well as descriptions of rainy/dry days and individual storms, the timing of the onset of the rainy season, and the relative wetness/dryness of the season (Fig. 3).

\section{[Insert Fig. 3 here]}

The second category of documentary data encompasses descriptions of landscape conditions, from which climate may be inferred indirectly. Most important are accounts of the condition of individual or regional streams, rivers and lakes. Key categories of information include (for rivers) the occurrence of floods, months of maximum flow, height of the annual flood, wet versus dry season flow, navigability, and impacts of flooding upon transport and infrastructure, and (for lakes) the size of the lake, measured or relative height of the lake surface, and the desiccation of present-day lakes or appearance of lakes no longer existing.

The third, also climatically indirect, category of documentary data used for precipitation reconstruction (Nicholson, 2001b), includes descriptions of droughts, famines and associated agricultural information (e.g. the condition of crops, and the quality and quantity of annual harvests). Particular care is needed when interpreting accounts of drought and famine to establish where and when the event occurred, its severity, and, in the case of famine, whether it was due to climatic or other factors (e.g. disruption of agricultural production by conflict, disruption of food distribution networks by disease amongst draught animals). When interpreting harvest information, care is also needed to determine the exact crop type and, where possible, the approximate date of planting.

With all three categories of documentary data, it is necessary to establish contextual information about the observer and source. Most important is whether the information is an eyewitness testimony based on first-hand experience or a second hand account (Duncan, 1997). Unusual or extreme events are judged by individuals 
against a "normal" range of climatic conditions, which itself is a function of the nature and span of an individual's experience and the range of climate variability communicated through historical knowledge (Hassan, 2000). As such, it is also helpful to ascertain the background of individual observers and the length of time that they have been in a particular region, since their life history and experience of African climates could potentially impact upon their descriptions of conditions (Nash and Endfield, 2008).

Methodologies for analysing documentary materials for the purposes of climate reconstruction have been developed by a number of authors, but for Africa, the pioneer in this field is Sharon Nicholson. The approach used by Nicholson since her earliest publications is to scrutinise individual pieces of documentary data for the precipitation information contained, and then attribute a relative numerical score to each piece of data (in the range +3 to -3 ) according to how wet or dry, respectively, conditions appear to have been (see Nicholson, 1979, 1981; Nicholson et al., 2012a). The scores for individual hydrological years in specific geographic regions are then averaged to produce an index value for that region/year. Much of Nicholson's research into African precipitation variability (e.g. Nicholson, 1981, 1996, 2000, 2001a; Nicholson et al., 2012a) has drawn mainly from published historical sources. Other reconstructions, such as those undertaken for the southern and eastern Cape (Vogel, 1989), the Kalahari Desert (Nash, 1996; Endfield and Nash, 2002; Nash and Endfield, 2002a, 2002b, 2008), Namaqualand (Kelso and Vogel, 2007), Lesotho (Nash and Grab, 2010) and KwaZulu-Natal (Hannaford et al., 2015; Nash et al., 2016), have used a greater proportion of unpublished materials and have employed a slightly different approach. With the exception of Hannaford et al. (2015), whose research is based on analyses of ships' logs, these studies have tended to look at the evidence of overall rainfall conditions provided by collections of documentary data for specific seasons or years, rather than scoring individual documents. The discrepancies introduced by these different approaches are considered in more detail in section 4.

\subsection{Natural palaeoclimate proxy evidence}

Much of our knowledge of rainfall variability in southern Africa for periods prior to the start of the written and instrumental record, comes from natural palaeoclimate 
proxies. In comparison with regions such as Europe and North America, however, high-resolution and well-dated proxy records covering recent centuries are relatively scarce. In many cases, this is a product of the nature of southern African environments themselves. Tree ring records, demonstrably well-suited for reconstructing past rainfall variability in other parts of the world, are mostly lacking in the subcontinent (for exceptions, see Hall, 1976; Dunwiddie and LaMarche, 1980; Therrell et al., 2006; Woodborne et al., 2015). In part, this is due to tree species suitable for dendroclimatological reconstruction being scarce, since climatic conditions fail to drive the seasonal variation in wood growth needed for the production of well-defined tree rings. Further, trees with demonstrably annual rings have little potential to be preserved intact long after death due to the widespread occurrence of wood-eating insect species such as termites.

In addition to a comparative dearth of tree ring data, southern Africa is underrepresented in terms of well-dated high-resolution lake-sediment records compared to the rest of the continent. Pollen records are also often poorly dated and of low resolution, with the complex nature of the subcontinent's flora making fossil pollen assemblages hard to interpret in terms of their past climatic significance (see Meadows et al., 2010; Chase et al., 2015). As a result, a diverse range of other climate archives, including isotopic fluctuations within cave speleothems (e.g. Holmgren et al., 2003), and isotope and pollen data from hyrax middens (e.g. Chase et al., 2012), have additionally been explored (Hannaford and Nash, 2016). Although of lower temporal resolution than instrumental and documentary data, interesting insights into rainfall variability during recent centuries can be obtained.

\section{Rainfall variability and change, 1800 -present}

\subsection{Precipitation variability during the 19th century}

The main annually-resolved precipitation reconstructions for southern Africa that span the 19th century are shown in Fig. 4. These include documentary-derived series for the southern and eastern Cape (Vogel, 1989), the Kalahari (Nash and Endfield, 2002a, 2008), Namaqualand (Kelso and Vogel, 2007), Lesotho (Nash and Grab, 2010), and KwaZulu-Natal (Nash et al., 2016), plus two reconstructions based on wind data within ships' logbooks for the Eastern Cape and KwaZulu-Natal 
(Hannaford et al., 2015). A semi-quantitative rainfall reconstruction for western Zimbabwe based on tree ring widths (Therrell et al., 2006), and separate reconstructions for four regions of the subcontinent based on combined documentary and early gauge data (Nicholson et al., 2012a), are also presented. Collectively, these series permit the identification of subcontinent-wide severe and/or protracted drought, as well as wetter episodes, in both the SRZ and WRZ.

\section{[Insert Fig. 4 here]}

In the SRZ, drought episodes can be identified during the first decade of the 19th century, in the early and late 1820 s, late 1850 s-mid 1860 s, mid-late 1870 s, early-mid 1880 s and mid-late 1890s. Individual studies suggest that, of these, the drought during the early 1860 s was the most severe of the 19th century, with the droughts of the 1820 s and 1890 s the most protracted. The early 1860 s drought affected areas of the $S R Z$ at least as far north as Zimbabwe and west as Namaqualand. The drought commenced in most regions with below average rainfall in 1860-61, and continued through to at least the 1862-63 summer rainy season. In Lesotho, there were widespread accounts of harvest failure, the cessation of trading between major population centres, and increases in food prices resulting in famine (Nash and Grab, 2010). In Namaqualand, the drought episode was the first of the 19th century for which government assistance was proposed (Kelso and Vogel, 2007), while in parts of former Zululand, the impact of the drought upon food supplies and livestock appears to have triggered social conflict and unrest (Nash et al., 2016).

The mid-late 1890s drought appears to have followed a similar pattern to that of the early 1860s. Nash et al. (2016) report accounts from KwaZulu-Natal of hot, dry "berg" winds blowing from the north and northwest, in some cases, accompanied by blowing dust, in September and October 1895, at what would normally be the onset of the summer rainy season. This suggests that high pressure was sustained over the subcontinent interior at the start of the drought episode, a situation that is relatively common during SAM negative phases. The drought was unusually protracted. Kelso and Vogel (2007), for example, quote from a newspaper article entitled Cry from Namaqualand that described the dry spell as being "longer than living memory could parallel"2. The lack of rainfall had a devastating impact on

${ }^{2}$ Cape Times, 20 January 1896 
livestock and crop production, and was exacerbated by locust incursions in 1895 and the outbreak of the rinderpest (cattle plague) in 1896, resulting in famine relief measures being introduced in many parts of the subcontinent (Nash et al., 2016).

A number of studies have determined, at least qualitatively, an association between El Niño events and drought in the SRZ, in line with contemporary patterns (Nicholson and Kim, 1997; see section 2.2). Lindesay and Vogel (1990), for example, identified that all but three severe droughts in the Eastern Cape during the 19th and early 20th centuries correspond with more extreme ENSO warm phases. In the Kalahari, droughts are identified following at least 13 of the 17 single year and protracted El Niño events between 1840 and 1900 (Nash and Endfield, 2008). In Namaqualand, there is correspondence between 14 drought phases and El Niño events (Kelso and Vogel, 2007). The seasonal resolution of the reconstruction for KwaZulu-Natal (Nash et al., 2016) permits an even more detailed exploration of the ENSO-rainfall relationship. Of the 28 discrete El Niño years between 1836 and 1900 (as identified by Gergis and Fowler, 2009), 15 were associated with lower than average rainfall during the following austral summer. Of these rainy seasons, nine exhibited significantly reduced rainfall during January-March and/or April-June. A further three years that were classified as 'normal' overall also exhibited reduced rainfall during the summer and autumn transitional months. Seven El Niño years were followed by wetter than normal rainy seasons in the reconstruction. However, all but one of these years was prior to 1870 , and fell during a period when coral $\delta 180$ records from the SWIO indicate that the impact of ENSO on SSTs was less strong (Zinke et al., 2004). This is discussed further in section 4.2.

Widespread wetter conditions across the subcontinent are less easy to identify using the combination of tree ring width, documentary and gauge data shown in Fig. 4. The year 1816 appears to have been relatively wet across the Kalahari and other areas of south central Africa. Other wetter episodes are centred on the late 1830searly 1840 s, 1855,1870 and 1890 . The early 1890 s included a run of wetter years, particularly in the eastern half of the subcontinent. For example, very heavy rains were reported in January and February 1891 from the Eastern Cape and KwaZuluNatal northwards into present day, Botswana and Zimbabwe, and caused flooding, soil loss and considerable damage to crops (see Vogel, 1989; Nash and Endfield, 2008; Nash and Grab, 2010; Nash et al., 2016). 
In the WRZ, represented by the "Southern Cape" (Vogel, 1989) and "Cape Winter Rains" series (Nicholson et al., 2012a) on Fig. 4, drier conditions can be identified during the first decade of the 19th century, for much of the mid-late 1830s through to the mid-1840s, during the late 1850s and early 1860s, and in the early-mid 1880s and mid-late 1890s. Markedly wetter years are less easily picked out in the historical record, although the periods around 1815, the early 1830s, the mid 1840s, mid-late 1870 s and early 1890s saw enhanced rainfall. It is not easy to tell from the original studies which of these drier and wetter episodes were the most severe. However, by comparing the Cape Winter Rains series with the others presented by Nicholson et al. (2012a), droughts in the WRZ do not appear to have been as severe as those in the SRZ.

As Fig. 4 indicates, there are some discrepancies between individual rainfall reconstructions, particularly for the SRZ in the early part of the century. In most cases these are likely to reflect real regional differences in rainfall patterns. However, there appear to be more systematic variations between some series. For example, while the "South Central Africa" series generated by Nicholson et al. (2012a) from documentary and gauge data suggests protracted drought from 1800 to 1811, the overlapping tree-ring width series for Zimbabwe (Therrell et al., 2006) indicates periods of drought alternating with average or above-average rainfall during this time. The Nicholson et al. "Kalahari" series (which encompasses the Kalahari Desert, but extends to the east coast of South Africa) and overlapping Royal National Park series (Hannaford et al., 2015) show similar discrepancies.

The reasons for the differences between the reconstructions in Fig. 4 are unclear, but are likely to be due to methodological and/or evidence-based issues. The three combined documentary and gauge data reconstructions for the SRZ appear to overemphasise drought conditions relative to the other non-documentary proxy series. This is not an unexpected outcome, particularly given that the earliest part of these series are almost entirely based on documentary data. As noted in section 3.2, the types of environmental evidence recorded in historical documents are strongly affected by the life experience of the author (Hassan, 2000). It would not be surprising if observers originating from Europe tended to overemphasise drought conditions when describing the climate and environment of southern Africa. 


\subsection{Trends in precipitation variability over the last 200 years}

While compilations of rainfall reconstructions, such as those shown in Fig. 5, are useful for identifying major wetter and drier episodes during the 19th century, they cannot easily be used to identify long-term rainfall trends. To overcome this issue, Neukom et al. (2014) developed separate annually-resolved multi-proxy precipitation reconstructions for the WRZ (Fig. 5a) and SRZ (Fig. 5c), spanning the last 200 years. The reconstructions incorporated two sets of data. Precipitation totals for ONDJFM and AMJJAS in the CRU TS 3.0 grid (updated from Mitchell and Jones, 2005) were used as the instrumental rainfall dataset. These data were statistically integrated alongside all of the series in Fig. 4 plus, for the WRZ, early instrumental data from the Royal Observatory in Cape Town and tree-ring width data from Die Bos in the Western Cape (Dunwiddie and LaMarche, 1980), and for the SRZ, coral $\delta^{18} \mathrm{O}$ and $\mathrm{Sr} / \mathrm{Ca}$ data from Mayotte (Zinke et al., 2009) and Ifaty, Madagascar (Zinke et al., 2004).

\section{[Insert Fig. 5 here]}

The SRZ reconstruction was updated by Nash et al. (2016) with the inclusion of the documentary series from KwaZulu-Natal show in Fig. 4, ships' log-derived rainfall reconstructions from Mthatha and Royal National Park (Hannaford et al., 2015), and the 19th and 20th century section of the baobab tree ring isotope series produced by Woodborne et al. (2015). The latter series is excluded from Fig. 5c, as the data do not introduce additional signal to the reconstruction and led to lower verification skill (see Nash et al., 2016, for further explanation). Both reconstructions show good statistical agreement with selected independent palaeoclimate time series, including documentary and coral isotope data, and wind speed information from the CLIWOC/ICOADS database (Garcia-Herrera et al., 2005; Nicholson et al., 2012a; Grove et al., 2013).

Reconstructed rainfall anomalies for the WRZ are shown in Fig. 5a. There is no significant offset in mean rainfall levels between the 19th and 20th centuries, suggesting that overall rainfall levels have not changed markedly during the last 200 years. Decadal-scale dry periods are reconstructed centred around 1835, 1930 and 1965, while wetter conditions occurred around 1890, 1920, and 1950. The driest 
years of the 19th (20th) century include 1825, 1827, and $1865(1935,1960$, and 1973), and the wettest are 1888, 1892, and 1989 (1993, 1989, and 1977). There is a small but statistically significant increase in reconstructed rainfall variability over the period of reconstruction, suggesting greater rainfall variability during the 20th century compared to the 19th century.

In contrast, reconstructed rainfall anomalies for the SRZ suggest that, on average, the SRZ was significantly wetter in the 19th than the 20th century. Furthermore, there appears to be a drying trend during the 20th century that has continued into the early 21st century (Nash et al., 2016). Modest downward trends in precipitation during the latter 20th century have been identified in Botswana, Zimbabwe and Western South Africa from instrumental data (Niang et al., 2014), but this reconstruction confirms that drying began much earlier. Relatively dry intervals are reconstructed centred on 1827 and 1862, the latter of which was the driest year of the 19th century. Wetter intervals are reconstructed around 1815, 1872 and 1890, with 1813 being the wettest year of the multi-proxy reconstruction.

A comparison of the $\mathrm{WRZ}$ and $\mathrm{SRZ}$ series reveals some interesting patterns. Unsurprisingly, given their different synoptic controls, rainfall levels in the SRZ and WRZ are only weakly correlated at interannual timescales. On decadal timescales there is better agreement, but, as Fig. 5 shows, rainfall fluctuations are not always synchronous. While there are some very dry and very wet decadal-scale periods present across both rainfall zones (e.g. dry around 1930, wet around 1890), there are also periods of contrasting anomalies. For example, a wet SRZ and dry WRZ occurs during the late 1830s and 1960s. The late 19th century was the wettest period identified in the 30-year filtered reconstructions for both rainfall zones; significantly, the period around 1890 was also one of the wettest of the last 200 years in south-eastern Australia (Gergis et al., 2012; Gergis and Ashcroft, 2013).

Fig. 5b and d display 30-year running correlations of the reconstructed WRZ and SRZ rainfall, respectively, with reconstructions of the main large-scale modes of climate variability affecting southern African precipitation (see section 1). The relationship between SRZ rainfall and the Southern Oscillation Index (SOI; Stahle et al., 1998) is significantly positive over the full period of reconstruction, apart from clear breakdowns in running correlations from c.1830-1875 and c.1930-1960 (see 
Neukom et al., 2014, for a discussion). As noted above, the timing of these breakdowns coincides with weakening of the ENSO-rainfall relationship identified from analyses of coral $\delta 180$ and/or documentary data from sites around the Indian Ocean rim (e.g. Zinke et al., 2004; Adamson and Nash, 2014; Ashcroft et al., 2015), suggesting a basin-wide shift in ENSO teleconnections during the mid-19th and mid20th centuries (Nash et al., 2016). In contrast, there is only an unstable and mostly weak relationship between WRZ rainfall and SOI over the same period.

SRZ rainfall show a stable and consistently negative correlation over time with Indian Ocean SSTs, confirming their importance as a driver of precipitation in this zone. The same is true of the relationship between Southern Ocean SSTs and WRZ rainfall, except that the correlation is positive. There are only weak, unstable and rarely significant correlations between reconstructed SAM index values (Jones et al., 2009; Villalba et al., 2012) and rainfall in both the SRZ and WRZ. Neukom et al. (2014) note that correlations of SRZ rainfall with both the SOI and Indian Ocean SSTs were relatively weak around 1950, a period where correlations with the SAM reconstruction of Jones et al. (2009) are above average. This suggests a stronger high-latitude influence on SRZ rainfall and a breakdown of tropical influence at this time. The much stronger and longer lasting breakdown of the relationship with the SOI from c.1830-1870 noted above does not, however, appear to have been associated with a strengthening of the SAM teleconnection.

\section{Directions for future research}

As this article demonstrates, we have a good understanding of interannual precipitation variability over much of the southern African subcontinent, spanning at least the last 200 years. There are, however, a number of avenues for further research. First, studies targeting rainfall variability during the late 18th and early 19th centuries are needed to increase the robustness and skill of the multiproxy reconstructions shown in Fig. 5. Documentary-derived reconstructions for this time period are only likely to be possible for areas with the longest histories of European settlement (e.g. the Western Cape, and former Portuguese trading posts and garrisons in southeast Africa). Second, high resolution records are needed to fill the gaps in our geographical coverage of historical rainfall variability (see Fig. 5). Areas 
such as present-day Madagascar, Malawi, Mozambique, Namibia and Zambia, for which largely unexploited collections of historical materials are archived in southern Africa and Europe, offer the greatest opportunity. Finally, there is considerable potential for historical climatology research using written records from early Portuguese settlements in southeast Africa, many of which extend back to the 16th century. As Hannaford and Nash (2016) discuss, much of these materials focus on trade, exploitation and African-Portuguese relations. However, from their provisional analyses, clusters of severe and protracted climate events can be identified, including food shortages and drought on the Mozambique coast (1506-1518), protracted dry conditions in the Zambezi Valley (1730-1768), and region-wide droughts in 1560-1590, 1795-1805 and 1824-1830. Detailed investigations of historical collections held in Lisbon and elsewhere are sure to yield valuable new evidence of interannual rainfall variability for the subcontinent.

\section{Acknowledgements}

The author acknowledges support from the Leverhulme Trust (Research Project Grant number F/00 504/D) for this study. Thanks also to Raphael Neukom for the production of Figures 1 and 5. 


\section{References}

Abram, N.J., Gagan, M.K., Cole, J.E., Hantoro, W.S., and Mudelsee, M. (2008). "Recent intensification of tropical climate variability in the Indian Ocean." Nature Geoscience 1: 849-853.

Adamson, G.C.D. (2015). "Private diaries as information sources in climate research." WIREs Climate Change 6: 599-611.

Adamson, G.C.D., and Nash, D.J. (2014). "Documentary reconstruction of monsoon rainfall variability over western India, 1781-1860." Climate Dynamics 42: 749-769.

Ash, K.D., and Matyas, C.J. (2012). "The influences of ENSO and the subtropical Indian Ocean Dipole on tropical cyclone trajectories in the southwestern Indian Ocean." International Journal of Climatology 32: 41-56.

Ashcroft, L., Gergis, J., and Karoly, D.J. (2015). "Long-term stationarity of El NiñoSouthern Oscillation teleconnections in southeastern Australia." Climate Dynamics 46: 2991-3006.

Barber, F.H.A. (1910). "Is South Africa drying up?" Agricultural Journal of the Cape of Good Hope 86: 167-170.

Barrow, J. (1801). Account of Travels into the Interior of Southern Africa, Vol. 1 (London: T. Cadell Jnr and W. Davies).

Barrow, J. (1804). Account of Travels into the Interior of Southern Africa, Vol. 2 (London: T. Cadell Jnr and W. Davies).

Behera, S.K., and Yamagata, T. (2001). "Subtropical SST dipole events in the southern Indian ocean." Geophysical Research Letters 28: 327-330.

Brown, M.L. (2009). "Madagascar's cyclone vulnerability and the global vanilla economy." In: E.C. Jones and A.D. Murphy (eds.), The Political Economy of Hazards and Disasters (New York: Altamira Press), pp.241-264.

Campbell, J. (1822). Travels in South Africa, 2 Vols (London: London Missionary Society).

Chang-Seng, D.S., and Jury, M.R. (2010). "Tropical cyclones in the SW Indian Ocean. Part 1: inter-annual variability and statistical prediction." Meteorology and Atmospheric Physics 106: 149-162.

Chase, B.M., and Meadows, M.E. (2007). "Late Quaternary dynamics of southern Africa's winter rainfall zone." Earth-Science Reviews 84: 103-138.

Chase, B.M., Lim, S., Chevalier, M., Boom, A., Carr, A.S., Meadows, M.E., and Reimer, P.J. (2015). "Influence of tropical easterlies in southern Africa's winter rainfall zone during the Holocene." Quaternary Science Reviews 107: 138-148.

Chase, B.M., Scott, L., Meadows, M.E., Gil-Romera, G., Boom, A., Carr, A.S., Reimer, P.J., Truc, L., Valsecchi, V., and Quick, L.J. (2012). "Rock hyrax middens: a palaeoenvironmental archive for southern African drylands." Quaternary Science Reviews 56: 107-125.

Cox, G.W. (1925). "Periodicity in rainfall." Transactions of the Royal Society South Africa 12: 295-299.

Duncan, J. (1997). "Sites of representation - place, time and the discourse of the other." In: J. Duncan and D. Ley (eds.), Place, culture and representation (London: Routledge), pp.39-56.

Dunwiddie, P.W., and LaMarche, V.C. (1980). "A climatically responsive tree-ring record from Widdringtonia cedarbergensis, Cape Province, South Africa." Nature 286: 796-797.

Endfield, G.H., and Nash, D.J. (2002). "Drought, desiccation and discourse: missionary correspondence and nineteenth-century climate change in central southern Africa." Geographical Journal 168: 33-47. 
Favre, A., Hewitson, B., Lennard, C., Cerezo-Mota, R., and Tadross, M.A. (2013). "Cut-off Lows in the South Africa region and their contribution to precipitation." Climate Dynamics 41: 2331-2351.

Fitchett, J.M., and Grab, S.W. (2014). "A 66-year tropical cyclone record for southeast Africa: temporal trends in a global context." International Journal of Climatology 34: 3604-3615

Funk, C., Dettinger, M.D., Michaelsen, J.C., Verdin, J.P., Brown, M.E., Barlow, M., and Hoell, A. (2008). "Warming of the Indian Ocean threatens eastern and southern African food security but could be mitigated by agricultural development." Proceedings of the National Academy of Sciences of the United States of America 105: $11081-11086$.

Garcia-Herrera, R., Konnen, G.P., Wheeler, D.A., Prieto, M.R., Jones, P.D., and Koek, F.B. (2005). "CLIWOC: A climatological database for the world's oceans 1750-1854." Climatic Change 73: 1-12.

Gergis, J., and Ashcroft, L. (2013). "Rainfall variations in south-eastern Australia, Part 2: a comparison of documentary, early instrumental and palaeoclimate records, 1788-2008." International Journal of Climatology 33: 2973-2987.

Gergis, J., Gallant, A., Braganza, K., Karoly, D.J., Allen, K., Cullen, L., D'Arrigo, R.D., Goodwin, I., Grierson, P., and McGregor, S. (2012). "On the long-term context of the 1997-2009 "Big Dry" in south-eastern Australia: insights from a 206-year multiproxy rainfall reconstruction." Climatic Change 111: 923-944.

Gergis, J.L., and Fowler, A.M. (2009). "A history of ENSO events since A.D. 1525: implications for future climate change." Climatic Change 92: 343-387.

Gillett, N.P., Kell, T.D., and Jones, P.D. (2006). "Regional climate impacts of the Southern Annular Mode", Geophysical Research Letters, 33: DOI: 10.1029/2006GL027721.

Goddard, L., and Graham, N.E. (1999). "Importance of the Indian Ocean for simulating rainfall anomalies over eastern and southern Africa." Journal of Geophysical Research 104: 19099-19116.

Gregory, P.J., Ingram, J.S.I., and Brklacich, M. (2005). "Climate change and food security." Philosophical Transactions of the Royal Society B: Biological Sciences 360: 2139-2148.

Grove, C.A., Zinke, J., Peeters, F., Park, W., Scheufen, T., Kasper, S., Randriamanantsoa, B., McCulloch, M.T., and Brummer, G.-J.A. (2013). "Madagascar corals reveal a multidecadal signature of rainfall and river runoff since 1708." Climate of the Past 9: 641-656.

Hall, M. (1976). "Dendrochronology, rainfall and human adaptations in the Later Stone Age of Natal and Zululand." Annals of the Natal Museum 22: 693-703.

Hannaford, M.J., and Nash, D.J. (2016). "Climate, history, society over the last millennium in southeast Africa." WIREs Climate Change 7: 370-392.

Hannaford, M.J., Jones, J.M., and Bigg, G.R. (2015). "Early-nineteenth-century southern African precipitation reconstructions from ships' logbooks." The Holocene 25: 379-390.

Hassan, F. (2000). "Environmental perception and human responses in history and prehistory." In: R.J. Mclntosh, J.A. Tainter, and S.K. Mclntosh (eds.), The way the wind blows: climate, history and human action (New York: Columbia University press), pp.121-140.

Ho, C.-H., Kim, J.-H., Jeong, J.-H., Kim, H.-S., and Chen, D. (2006). "Variation of tropical cyclone activity in the South Indian Ocean: El Niño-Southern Oscillation 
and Madden-Julian Oscillation effects", Journal of Geophysical ResearchAtmospheres, 111: DOI: 10.1029/2006jd007289.

Holmgren, K., Lee-Thorp, J.A., Cooper, G.R.J., Lundblad, K., Partridge, T.C., Scott, L., Sithaldeen, R., Talma, A.S., and Tyson, P.D. (2003). "Persistent millennialscale climatic variability over the past 25,000 years in Southern Africa." Quaternary Science Reviews 22: 2311-2326.

Hutchins, D.E. (1888). Cycles of Drought and Good Seasons in South Africa (Wynberg: Wynberg Times).

Jackson, S.P. (1942). Weather on the coasts of South Africa, Parts 1 to 5 (Pretoria: Meteorological Services of the Royal Navy and South African Air Force).

Jackson, S.P. (1961). Climatological Atlas of Africa (Nairobi: CCTA/CSA).

Jones, J.M., Fogt, R.L., Widmann, M., Marshall, G.J., Jones, P.D., and Visbeck, M. (2009). "Historical SAM Variability. Part I: Century-length seasonal reconstructions." Journal of Climate 22: 5319-5345.

Jury, M.R. (1993). "A preliminary-study of climatological associations and characteristics of tropical cyclones in the SW Indian Ocean." Meteorology and Atmospheric Physics 51: 101-115.

Jury, M.R. (1995). "A review of research on ocean-atmosphere interactions and South African climate variability." South African Journal of Science 91: 289-294.

Jury, M.R. (1996). "Regional teleconnection patterns associated with summer rainfall over South Africa, Namibia and Zimbabwe." International Journal of Climatology 16: 135-153.

Kelso, C., and Vogel, C.H. (2007). "The climate of Namaqualand in the nineteenth century." Climatic Change 83: 257-380.

Kokot, D.F. (1948). An investigation into the evidence bearing on recent climatic changes over southern Africa (Pretoria: Department of Irrigation, Union of South Africa).

Kuleshov, Y., Qi, L., Fawcett, R., and Jones, D. (2008). "On tropical cyclone activity in the Southern Hemisphere: Trends and the ENSO connection", Geophysical Research Letters, 35: DOI: 10.1029/2007gl032983.

Le Vaillant, F. (1796). New Travels into the Interior Parts of Africa, Volumes 1-3 (London: Robinson).

Leroy, A., and Wheeler, M.C. (2008). "Statistical prediction of weekly tropical cyclone activity in the Southern Hemisphere." Monthly Weather Review 136: 3637-3654.

Lindesay, J.A. (1988). "South-African rainfall, the Southern Oscillation and a southern hemisphere semi-annual cycle." Journal of Climatology 8: 17-30.

Lindesay, J.A., and Vogel, C.H. (1990). "Historical evidence for South OscillationSouthern African rainfall relationships." International Journal of Climatology 10: 679-689.

Lindesay, J.A., Harrison, M.S.J., and Haffner, M.P. (1986). "The Southern Oscillation and South African rainfall." South African Journal of Science 82: 196-197.

Livingstone, D. (1857). Missionary travels and researches in South Africa (London: John Murray).

MacKellar, N.C., Hewitson, B.C., and Tadross, M.A. (2007). "Namaqualand's climate: recent historical changes and future scenarios." Journal of Arid Environments 70: 604-614.

Mason, S.J. (1995). "Sea-surface temperature - South-African rainfall associations, 1910-1989." International Journal of Climatology 15: 119-135. 
Mason, S.J., and Jury, M.R. (1997). "Climatic variability and change over southern Africa: a reflection on underlying processes." Progress in Physical Geography 21: 23-50.

Mavume, A.F., Rydberg, L., Rouault, M., and Lutjeharms, J.R.E. (2009). "Climatology and landfall of tropical cyclones in the south-west Indian Ocean." Western Indian Ocean Journal of Marine Science 8: 15-35.

Meadows, M.E., Chase, B.M., and Seliane, M. (2010). "Holocene palaeoenvironments of the Cederberg and Swartruggens mountains, Western Cape, South Africa: pollen and stable isotope evidence from hyrax dung middens." Journal of Arid Environments 74: 786-793.

Meque, A., and Abiodun, B.J. (2015). "Simulating the link between ENSO and summer drought in Southern Africa using regional climate models." Climate Dynamics 44: 1881-1900.

Mitchell, T.D., and Jones, P.D. (2005). "An improved method of constructing a database of monthly climate observations and associated high resolution grids." International Journal of Climatology 25: 693-712.

Moffat, R. (1842). Missionary Labours and Scenes in South Africa (London: J. Snow).

Nash, D.J. (1996). "On the dry valleys of the Kalahari: Documentary evidence of environmental change in central southern Africa." Geographical Journal 162: 154168.

Nash, D.J., and Endfield, G.H. (2002a). "A 19th century climate chronology for the Kalahari region of central southern Africa derived from missionary correspondence." International Journal of Climatology 22: 821-841.

Nash, D.J., and Endfield, G.H. (2002b). "Historical flows in the dry valleys of the Kalahari identified from missionary correspondence." South African Journal of Science 98: 244-248.

Nash, D.J., and Endfield, G.H. (2008). "'Splendid rains have fallen': links between El Nino and rainfall variability in the Kalahari, 1840-1900." Climatic Change 86: 257290.

Nash, D.J., and Grab, S.W. (2010). "'A sky of brass and burning winds": documentary evidence of rainfall variability in the Kingdom of Lesotho, Southern Africa, 1824-1900." Climatic Change 101: 617-653.

Nash, D.J., and Adamson, G.C.D. (2014). "Recent advances in the historical climatology of the tropics and subtropics." Bulletin of the American Meteorological Society 95: 131-146.

Nash, D.J., Pribyl, K., Klein, J., Endfield, G.H., Kniveton, D.R., and Adamson, G.C.D. (2015). "Tropical cyclone activity over Madagascar during the late nineteenth century." International Journal of Climatology 35: 3249-3261.

Nash, D.J., Pribyl, K., Klein, J., Neukom, R., Endfield, G.H., Adamson, G.C.D., and Kniveton, D.R. (2016). "Seasonal rainfall variability in southeast Africa during the nineteenth century reconstructed from documentary sources." Climatic Change 134: 605-619.

Neukom, R., Nash, D.J., Endfield, G.H., Grab, S.W., Grove, C.A., Kelso, C., Vogel, C.H., and Zinke, J. (2014). "Multi-proxy summer and winter precipitation reconstruction for southern Africa over the last 200 years." Climate Dynamics 42: 2713-2716.

Nevill, E. (1908). "The rainfall in Natal." Agricultural Journal of Natal 11: 1531-1533.

Niang, I., Ruppel, O.C., Abdrabo, M.A., Essel, A., Lennard, C., Padgham, J., and Urquhart, P. (2014). "Africa." In: V.R. Barros, et al. (eds.), Climate Change 2014: 
Impacts, Adaptation, and Vulnerability. Part B: Regional Aspects (Cambridge: Cambridge University Press), pp.1199-1265.

Nicholson, S.E. (1979). "The methodology of historical climate reconstruction and its application to Africa." Journal of African History 20: 31-49.

Nicholson, S.E. (1981). "The Historical Climatology of Africa." In: T.M.L. Wigley, M.J. Ingram, and G. Farmer (eds.), Climate and History (Cambridge: Cambridge University Press), pp.249-270.

Nicholson, S.E. (1996). "Environmental Change within the Historical Period." In: A.S. Goudie, Adams, W. M., and Orme, A. (ed.), The Physical Geography of Africa (Oxford: Oxford University Press), pp.60-75.

Nicholson, S.E. (2000). "The nature of rainfall variability over Africa on time scales of decades to millenia." Global and Planetary Change 26: 137-158.

Nicholson, S.E. (2001a). "Climatic and environmental change in Africa during the last two centuries." Climate Research 17: 123-144.

Nicholson, S.E. (2001b). "A semi-quantitative, regional precipitation data set for studying African climates of the nineteenth century, part 1. Overview of the data set." Climatic Change 50: 317-353.

Nicholson, S.E., and Entekhabi, D. (1986). "The quasi-periodic behavior of rainfall variability in Africa and its relationship to the Southern Oscillation." Archives for Meteorology Geophysics and Bioclimatology Series a-Meteorology and Atmospheric Physics 34: 311-348.

Nicholson, S.E., and Kim, E. (1997). "The relationship of the El Nino Southern Oscillation to African rainfall." International Journal of Climatology 17: 117-135.

Nicholson, S.E., and Selato, J.C. (2000). "The influence of La Nina on African rainfall." International Journal of Climatology 20: 1761-1776.

Nicholson, S.E., Leposo, D., and Grist, J.P. (2001). "The relationship between EI Niño and drought over Botswana " Journal of Climate 14: 323-335.

Nicholson, S.E., Klotter, D., and Dezfuli, A.K. (2012a). "Spatial reconstruction of semi-quantitative precipitation fields over Africa during the nineteenth century from documentary evidence and gauge data." Quaternary Research 78: 13-23.

Nicholson, S.E., Dezfuli, A.K., and Klotter, D. (2012b). "A two-century precipitation dataset for the continent of Africa." Bulletin of the American Meteorological Society 93: 1219-1231.

Rayner, N.A., Parker, D.E., Horton, E.B., Folland, C.K., Alexander, L.V., Rowell, D.P., Kent, E.C., and Kaplan, A. (2003). "Global analyses of sea surface temperature, sea ice, and night marine air temperature since the late nineteenth century", Journal of Geophysical Research-Atmospheres, 108: DOI: 10.1029/2002jd002670.

Reason, C.J.C. (2001). "Subtropical Indian Ocean SST dipole events and southern African rainfall." Geophysical Research Letters 28: 2225-2227.

Reason, C.J.C. (2007). "Tropical cyclone Dera, the unusual 2000/01 tropical cyclone season in the South West Indian Ocean and associated rainfall anomalies over Southern Africa." Meteorology and Atmospheric Physics 97: 181-188.

Reason, C.J.C., and Mulenga, H. (1999). "Relationships between South African rainfall and SST anomalies in the southwest Indian Ocean." International Journal of Climatology 19: 1651-1673.

Reason, C.J.C., and Rouault, M. (2002). "ENSO-like decadal variability and South African rainfall", Geophysical Research Letters, 29: DOI: 10.1029/2002GL014663. 
Reason, C.J.C., and Keibel, A. (2004). "Tropical Cyclone Eline and its unusual penetration and impacts over the southern African mainland." Weather and Forecasting 19: 789-805.

Reason, C.J.C., and Jagadheesha, D. (2005). "Relationships between South Atlantic SST variability and atmospheric circulation over the South African region during austral winter." Journal of Climate: 3339-3355.

Reason, C.J.C., Allan, R.J., Lindesay, J.A., and Ansell, T.J. (2000). "ENSO and climatic signals across the Indian Ocean basin in the global context: Part I, interannual composite patterns." International Journal of Climatology 20: 12851327.

Rocha, A., and Simmonds, I. (1997). "Interannual variability of south-eastern African summer rainfall. 1: relationships with air-sea interaction processes." International Journal of Climatology 17: 235-265.

Ropelewski, C.F., and Halpert, M.S. (1987). "Global and regional scale precipitation patterns associated with the El-Nino Southern Oscillation." Monthly Weather Review 115: 1606-1626.

Ropelewski, C.F., and Halpert, M.S. (1989). "Precipitation patterns associated with the high index phase of the Southern Oscillation." Journal of Climate 2: 268-284.

Schulze, B.R. (1972). "South Africa." In: J.F. Griffiths (ed.), Climates of Africa (Amsterdam: Elsevier), pp.501-586.

Schulze, B.R. (1984). Climate of South Africa: Part 8: General Survey, W.B.28 (Pretoria: South African Weather Bureau).

Schulze, R.E. (1997). "Atlas of Agro-Hydrology \& Agro-Climatology", WRC Report TT82/96 (Pretoria: Water Resource Commission).

Schulze, R.E. (2015). "South African atlas of agrohydrology and climatology, Beta 1.002", <http://planet.uwc.ac.za/NISL/Invasives/Assignments/GARP/atlas/atlas.htm>, accessed 26 February 2015.

Schwarz, E.H.L. (1920). The Kalahari or Thirstland Redemption (Cape Town: Maskew Miller).

Singleton, A.T., and Reason, C.J.C. (2007). "Variability in the characteristics of cutoff low pressure systems over subtropical southern Africa." International Journal of Climatology 27: 295-310.

Smith, J., Lee-Thorp, J., and Hall, S. (2007). "Climate change and agropastoralist settlement in the Shashe-Limpopo River basin." South African Archaeological Bulletin 62: 115-125.

Stahle, D.W., D'Arrigo, R.D., Krusic, P.J., Cleaveland, M.K., Cook, E.R., Allan, R.J., Cole, J.E., Dunbar, R.B., Therrell, M.D., Gay, D.A., Moore, M.D., Stokes, M.A., Burns, B.T., Villanueva-Diaz, J., and Thompson, L.G. (1998). "Experimental dendroclimatic reconstruction of the Southern Oscillation." Bulletin of the American Meteorological Society 79: 2137-2152.

Stoeckenius, T. (1981). "Interannual variations of tropical precipitation patterns." Monthly Weather Review 109: 1233-1207.

Therrell, M.D., Stahle, D.W., Ries, L.P., and Shugart, H.H. (2006). "Tree-ring reconstructed rainfall variability in Zimbabwe." Climate Dynamics 26: 677-685.

Tripp, W.B. (1888). "Rainfall of South Africa, 1842-1886." Quarterly Journal of the Royal Meteorological Society 14: 108-123.

Tyson, P.D. (1978). "Rainfall changes over South Africa during the period of meteorological record." In: M.J.A. Werger (ed.), Biogeography and Ecology of Southern Africa (The Hague: Dr W. Junk), pp.53-69. 
Tyson, P.D. (1986). Climatic Change and Variability in Southern Africa (Cape Town: Oxford University Press).

Tyson, P.D., and Preston-Whyte, R.A. (2000). The Weather and Climate of Southern Africa (Cape Town: Oxford University Press).

Tyson, P.D., Dyer, T.G.J., and Mametse, M.N. (1975). "Secular changes in South Africa and rainfall: 1880 to 1972." Quarterly Journal of the Royal Meteorological Society 101: 817-833.

UN Office for the Coordination of Humanitarian Affairs (2015). Southern Africa Humanitarian Outlook 2015/2016: Special Focus on El Niño (New York: UN $\mathrm{OCHA}$ ).

Van Heerden, J., Terblanche, D.E., and Schulze, G.C. (1988). "The Southern Oscillation and South African summer rainfall." Journal of Climatology 8: 577-597.

Villalba, R., Lara, A., Masiokas, M.H., Urrutia, R., Luckman, B.H., Marshall, G.J., Mundo, I.A., Christie, D.A., Cook, E.R., Neukom, R., Allen, K., Fenwick, P., Boninsegna, J.A., Srur, A.M., Morales, M.S., Araneo, D., Palmer, J.G., Cuq, E., Aravena, J.C., Holz, A., and LeQuesne, C. (2012). "Unusual Southern Hemisphere tree growth patterns induced by changes in the Southern Annular Mode." Nature Geoscience 5: 793-798.

Vitart, F., Leroy, A., and Wheeler, M.C. (2010). "A comparison of dynamical and statistical predictions of weekly tropical cyclone activity in the Southern Hemisphere." Monthly Weather Review 138: 3671-3682.

Vogel, C.H. (1989). "A documentary-derived climatic chronology for South Africa, 1820-1900." Climatic Change 14: 291-307.

Walker, N.D. (1990). "Links between South-African summer rainfall and temperature variability of the Agulhas and Benguela current systems." Journal of Geophysical Research-Oceans 95: 3297-3319.

Watterson, I.G. (2009). "Components of precipitation and temperature anomalies and change associated with modes of the Southern Hemisphere." International Journal of Climatology 29: 809-826.

Wilson, J.F. (1865). "Water supply in the basin of the Orange River or "Gariep South Africa"." Journal of the Royal Geographical Society 35: 106-129.

Woodborne, S., Hall, G., Robertson, I., Patrut, A., Rouault, M., Loader, N.J., and Hofmeier, M. (2015). "A 1000-year carbon isotope rainfall proxy record from South African baobab trees (Adansonia digitata L.)", PLOS ONE, 10: DOI: 10.1371/journal.pone.0124202.

Zinke, J., Dullo, W.C., Heiss, G.A., and Eisenhauer, A. (2004). "ENSO and Indian Ocean subtropical dipole variability is recorded in a coral record off southwest Madagascar for the period 1659 to 1995." Earth and Planetary Science Letters 228: 177-194.

Zinke, J., Pfeiffer, M., Timm, O., Dullo, W.-C., and Brummer, G. (2009). "Western Indian Ocean marine and terrestrial records of climate variability: a review and new concepts on land-ocean interactions since AD 1660." International Journal of Earth Sciences 98: 115-133. 


\section{Suggested readings:}

Nash, D.J., and Adamson, G.C.D. (2014). "Recent advances in the historical climatology of the tropics and subtropics." Bulletin of the American Meteorological Society 95: 131-146.

Nicholson, S.E. (2011). Dryland Climatology. Cambridge University Press.

Tyson, P.D. (1986). Climatic Change and Variability in Southern Africa (Cape Town: Oxford University Press). 


\section{List of Figures}

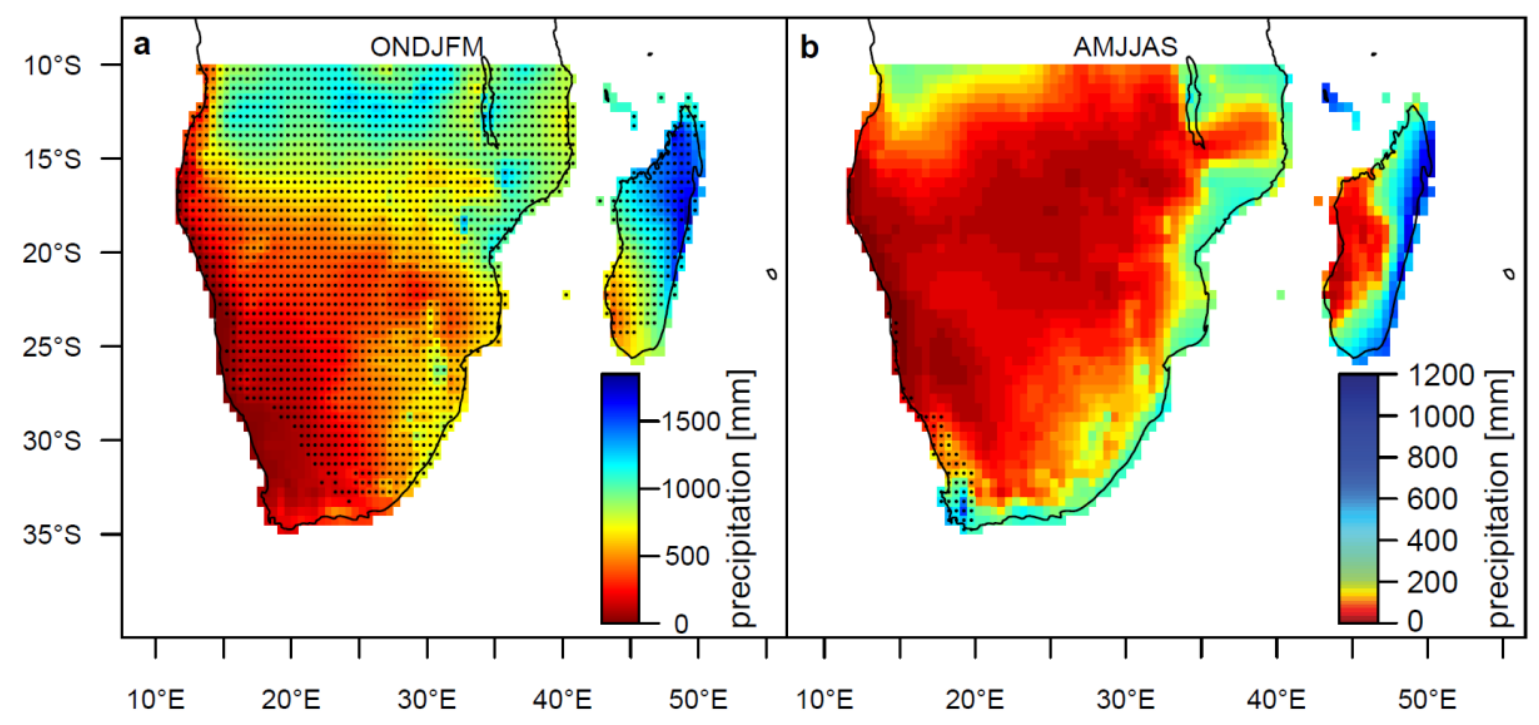

Figure 1: Seasonal rainfall totals over southern Africa for (a) the austral summer (ONDJFM) and (b) winter (AMJJAS) seasons in the CRU TS3.0 grid averaged over the 1901-2006 period. Grid cells in which $\geq 66 \%$ of precipitation occurs during ONDJFM (AMJJAS) are highlighted with black dots on panel a (panel b). 


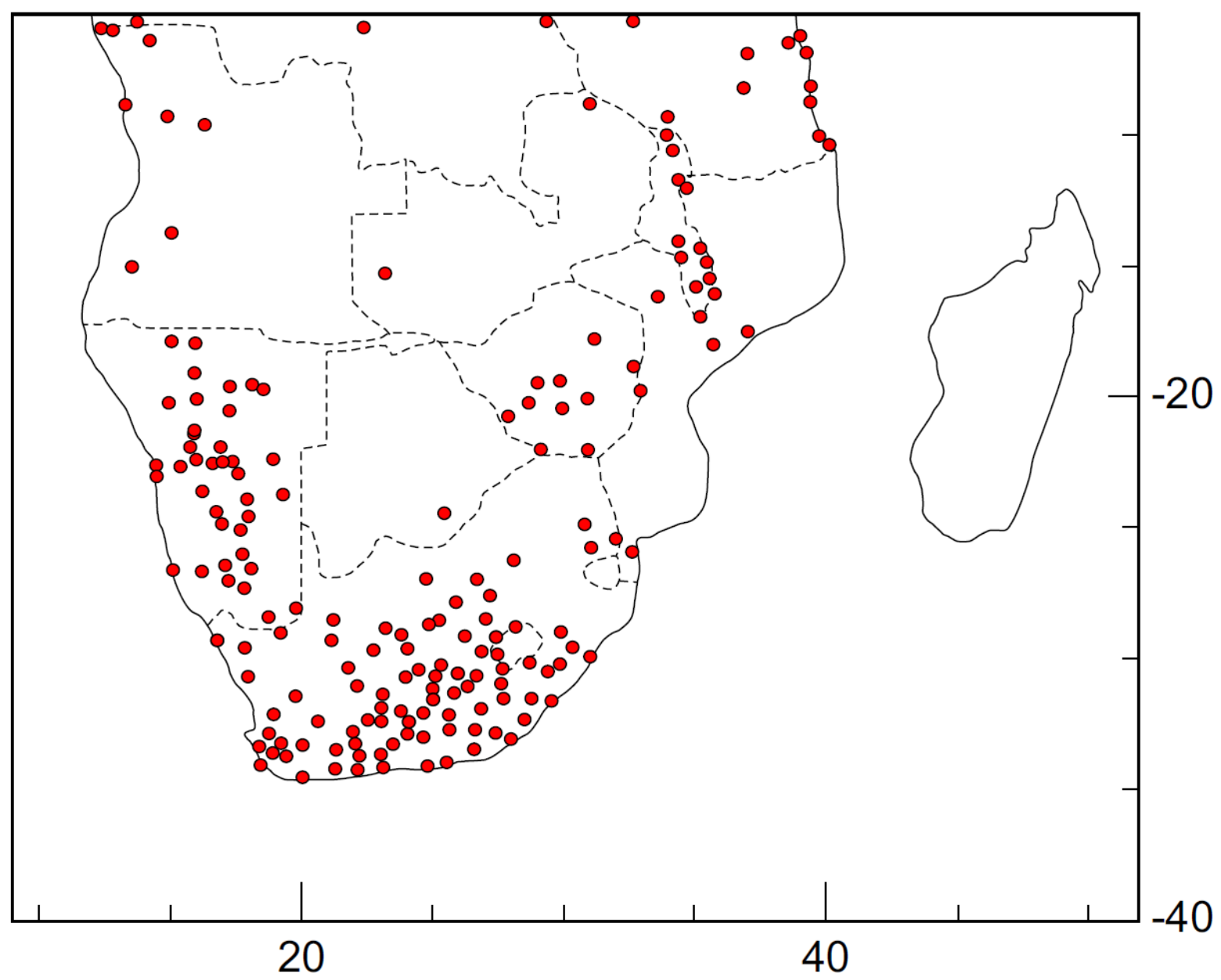

Figure 2: Map of locations in southern Africa with one or more years of precipitation data in the 19th century (station locations after Nicholson et al., 2012a). 

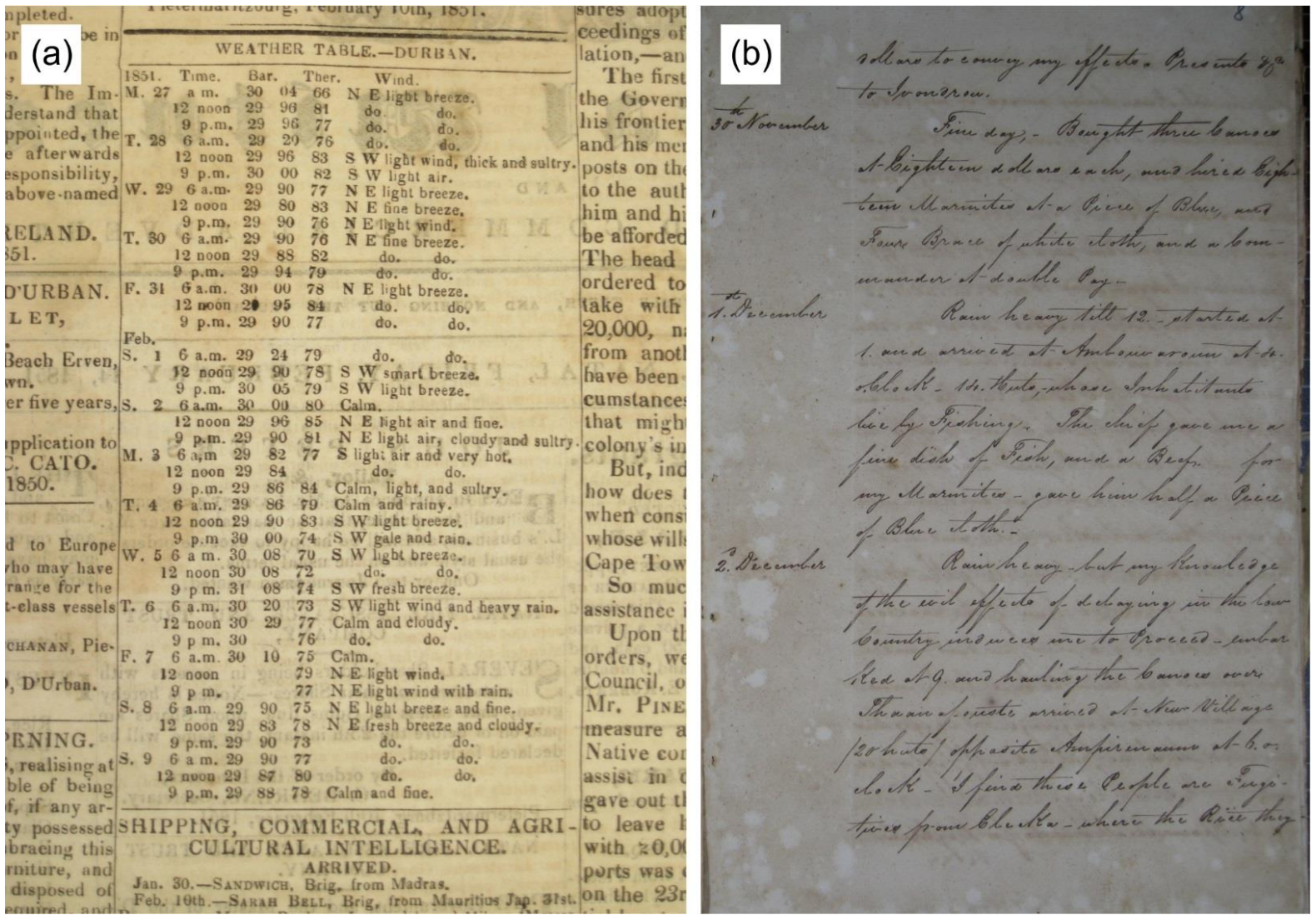

Figure 3: Examples of historical sources used for reconstruction of 19th century precipitation in southern Africa: (a) Table of early meteorological data for Durban (January-February 1851) from the Natal Witness newspaper; (b) Extract from the journal of Mr James Hastie, civil agent of the British government in Madagascar (1817-26), describing weather conditions during travels around Toamasina on the east coast in November-December 1817 (Mauritius National Archive, HB 10-01, Journal of Mr Hastie, from 14 November 1817 to 26 May 1818). 


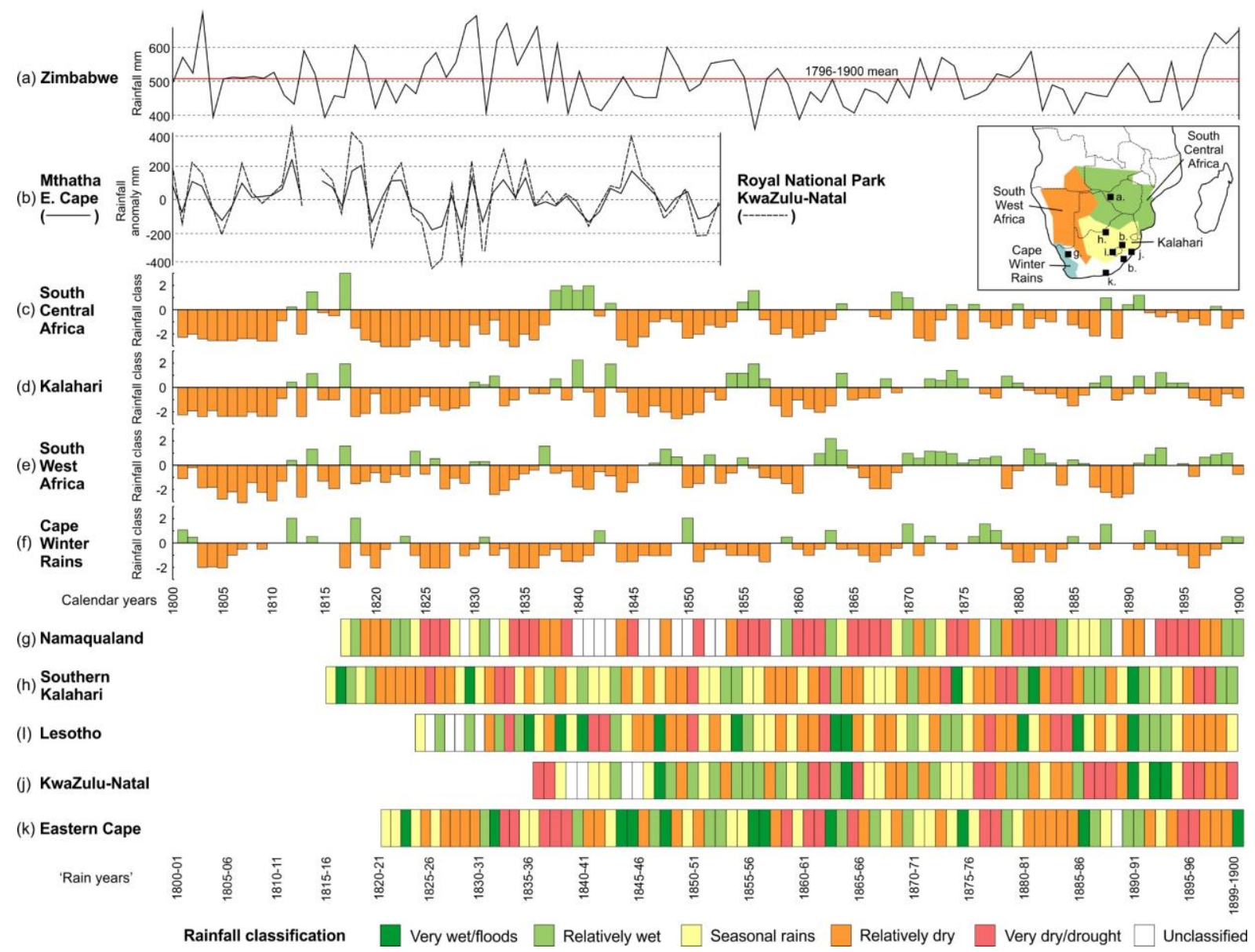

Figure 4: Annually resolved series of rainfall variability for the southern African summer and winter rainfall zones (1800-1900): (a) tree ring-width series for Zimbabwe (Therrell et al., 2006); (b) ships' logbook-derived series for Mthatha, Eastern Cape, and Royal National Park, KwaZulu-Natal (anomaly relative to 19792008 mean) (Hannaford et al., 2015); (c-f) documentary- and gauge data-derived series for 'South Central Africa' (Zambia, northeast Botswana, Zimbabwe, southern Mozambique), the 'Kalahari' (south Botswana, north/east South Africa), 'South West Africa' (southeast Angola, Namibia, northwest South Africa), and 'Cape Winter Rains' (southwest South Africa) (Nicholson et al., 2012a), (g-k) documentary-derived series for Namaqualand (Kelso and Vogel, 2007), southern Kalahari (Nash and Endfield, 2002a, 2008), Lesotho (Nash and Grab, 2010), KwaZulu-Natal (Nash et al., 2016) and Eastern Cape (Vogel, 1989). Inset map shows approximate locations of series. 


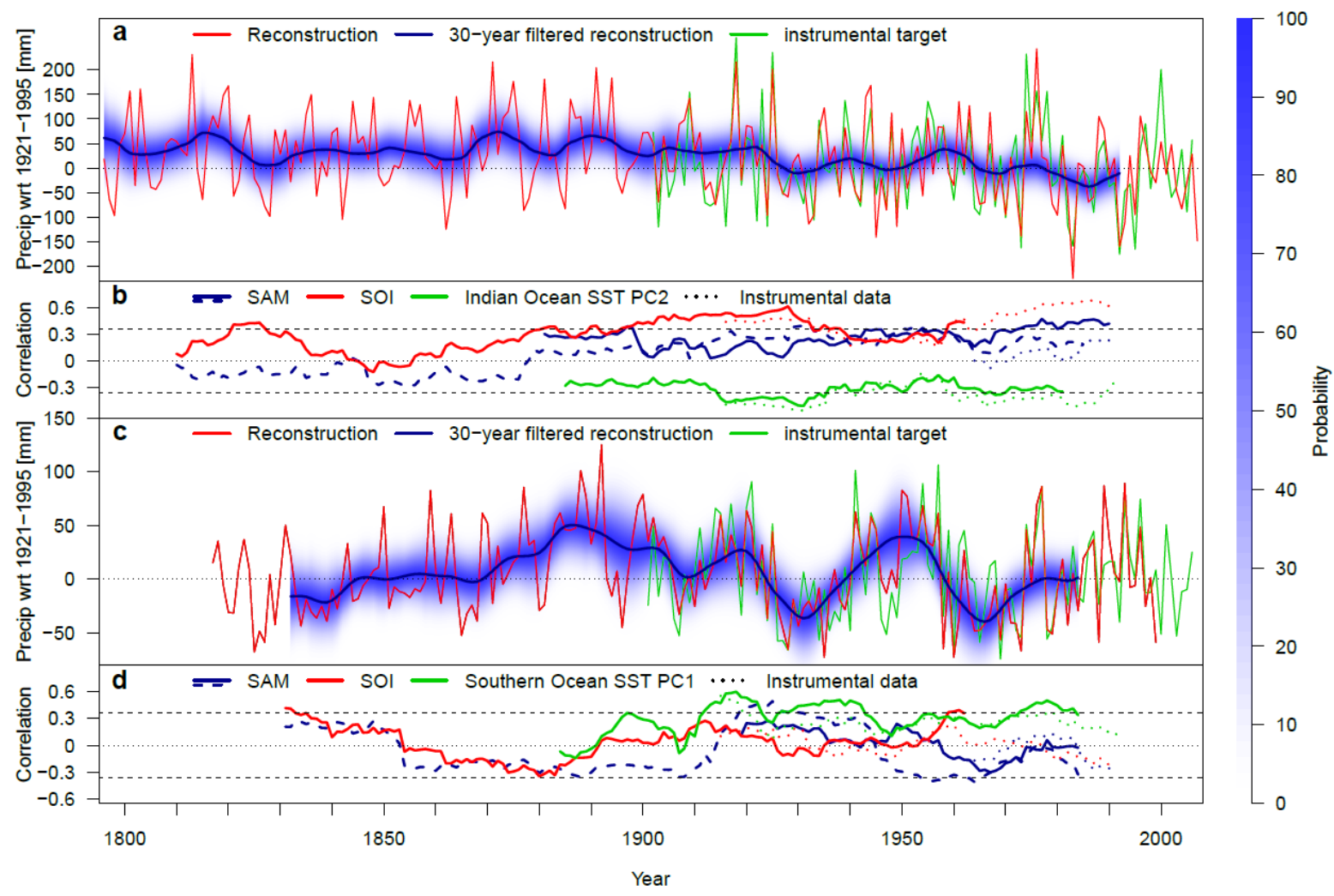

Figure 5: (a) Multiproxy precipitation reconstruction for the southern African Summer Rainfall Zone (SRZ) for 1796-2007 on interannual (red) and 30-year filtered (blue, with uncertainty bands shaded) timescales. Unfiltered instrumental data are shown in green. (b) 30-year running correlations of the $S R Z$ reconstruction with reconstructions of the SAM index (blue dashed; Villalba et al. 2012; blue solid; Jones et al. 2009); SOI index (red; Stahle et al. 1998) and Indian Ocean SST PC2 (green; HadISST data; Rayner et al., 2003). The dotted lines represent the correlations between the corresponding instrumental data. Data are plotted at the 15th year of each 30-year period. (c) and (d) Same as parts (a) and (b) but for the Winter Rainfall Zone (spanning 1817-1999), and with Southern Ocean SST PC1 instead of Indian Ocean SST PC2. Southern Ocean SST PC1 correlations are inverted. SRZ reconstructions and correlations from Nash et al. (2016) and WRZ from Neukom et al. (2014). 